\title{
Phellinus piptadeniae (Hymenochaetales: Hymenochaetaceae): taxonomy and host range of a species with disjunct distribution in South American seasonally dry forests
}

\author{
Carlos A. Salvador-Montoya • Gerardo L. Robledo • \\ Domingos Cardoso - Marco A. Borba-Silva • \\ Mariana Fernandes • Elisandro R. Drechsler-Santos
}

Received: 6 August 2014/ Accepted: 1 February 2015/Published online: 20 February 2015

(C) Springer-Verlag Wien 2015

\begin{abstract}
Phellinus piptadeniae (Hymenochaetaceae, Hymenochaetales) as currently accepted is characterized by having applanate to ungulate basidiome with the pilear surface concentrically sulcate, radially cracked in old specimens, and a sinuous black line in the context. The species has been recorded in seasonally dry forests of different Brazilian domains, often associated with legume hosts. It occurs highly specifically associated with Piptadenia gonoacantha in semideciduous forest of the Atlantic Forest domain in southeastern Brazil. In the Caatinga dry woodlands, northeastern Brazil, Phellinus piptadeniae occurs as host recurrent of different Piptadenia species. During recent polypore surveys, specimens that are morphologically similar to the type were collected in seasonally dry tropical forests (SDTFs) of northwestern Peru also
\end{abstract}

Handling editor: Pavel Lizon.

C. A. Salvador-Montoya - M. A. Borba-Silva ·

E. R. Drechsler-Santos $(\square)$

Departamento de Botânica, Centro de Ciências Biológicas,

Universidade Federal de Santa Catarina, Campus Universitário,

Trindade, Florianópolis, SC 88040-900, Brazil

e-mail: drechslersantos@yahoo.com.br; e.ricardo@ufsc.br

\section{G. L. Robledo}

Instituto Multidisciplinario de Biología Vegetal, Laboratorio de Micología, CC495, Universidad Nacional de Córdoba-

CONICET, CP 5000 Córdoba, Argentina

D. Cardoso

Departamento de Botânica, Instituto de Biologia, Universidade Federal da Bahia, Rua Barão de Jeremoabo, s/n, Campus Universitário de Ondina, Salvador, BA 40171-970, Brazil

\section{Fernandes}

Departamento de Microbiologia e Imunologia, Instituto de Biociências, Universidade Estadual Paulista, Campus de Botucatu, São Paulo 18618-970, Brazil on legume hosts (Libidibia glabrata and Pithecellobium excelsum). In this paper, we discuss the morphological variation, host range, and distribution of Phellinus piptadeniae in the context of the historical biogeography of the neotropical SDTF biome. Some taxonomic implications that should be further investigated in a molecular phylogenetic framework are also addressed.

Keywords Atlantic Forest · Brazil · Caatinga · Peru · Polypore

\section{Introduction}

The taxonomy of Hymenochaetales, the largest radiation of wood-decaying fungi (Floudas et al. 2012), has seen considerable advance in recent years (e.g., Larsson et al. 2006; Zhou and Dai 2011; He and Dai 2012; Amalfi and Decock 2013; Tian et al. 2013; Zhou and Qin 2013; Zhou 2014). However, poroid Hymenochaetales still remain under studied and under collected in the Neotropics, especially in the Seasonally Dry Tropical Forest (SDTF) biome (Drechsler-Santos et al. 2010, 2013). This is the case of the Phellinus piptadeniae Teixeira, a species herein shown to comprise widely disjunct populations that are largely confined to South American SDTF.

Teixeira (1950) pointed out that $P$. piptadeniae probably follows the geographical distribution of its highly specific host Piptadeniae communis (= Pip. gonoacantha), a common mimosoid legume distributed throughout the semideciduous forests of the Atlantic Forest and Cerrado domains in southern and central Brazil (Morim 2013). Sixty years after its original description, the species was rediscovered by Drechsler-Santos et al. (2010) during an ecological study in northeastern Brazil. As such, they expanded the 
distribution and host range of $P$. piptadeniae to different species of Piptadenia Benth., but also to species of Senegalia Raf. and Mimosa R.Br., in the Caatinga dry woodlands of Bahia, Ceará, Pernambuco, and Piauí states (Drechsler-Santos et al. 2010, 2013). Recently, during a survey of poroid Hymenochaetales in dry woodlands of northwestern Peru and in the Atlantic Forest of southeastern Brazil, we collected several specimens that were tentatively also determined as $P$. piptadeniae. These specimens unusually have basidiomata with a particular hyphal system in that the skeletal hyphae are restricted to the trama of tubes and the context is monomitic.

A critical comparison of the new collections from southeastern Brazil and Caatinga (Drechsler-Santos et al. 2010, 2013), and the widely disjunct population in Peru with the type of $P$. piptadeniae became necessary to establish a morphological circumscription of the species. We present a comparative morphological analysis of such collections and discuss the species and generic level taxonomy of $P$. piptadeniae. Its host specialization on legumes and apparent ecological predilection for neotropical seasonally dry forests are also commented.

\section{Materials and methods}

Study area and collections

Collections from Cabuyal ravine, Department of Piura, Northwest Peru, were made in 2012 in a lowland area of Seasonally Dry Tropical Forest (SDTF). In the Atlantic Forest of Brazil, collections were performed near the type locality, in São Paulo state, and in Santa Catarina state in 2013 and 2014. Specimens are kept at USM and FLOR herbaria (acronyms according to Thiers 2014, continuously updated).

\section{Morphological studies}

Size, shape, and color of basidiomata (pilear surface, context, tubes, pores, and dissepiment) as well as the pore surface (number of tubes strata and of pores per linear millimeter) were observed to describe seasonality. Colors were determined following Munsell Color Company (1975). Microscopical examination was achieved from freehand sections of specimens mounted in lactophenol (non-reaction), $3 \%(\mathrm{v} / \mathrm{w}) \mathrm{KOH}$ solution (xanthochroic), Melzer (dextrinoid or amyloid) and Cotton Blue (cyanophilia) reagents to determine the presence or absence of reactions. All microscopic measurements $(n=40)$ and drawings were made in $3 \%(\mathrm{v} / \mathrm{w}) \mathrm{KOH}$ solution. When presenting the size range of the microscopic elements, $5 \%$ of the measurements were excluded from each end and are given in parentheses. The following abbreviations are used throughout the text: $\mathrm{L}=$ longitude, $\mathrm{W}=$ wide, $\mathrm{Q}=$ the ratio of length/width and avg. = average of basidiospores measurements.

\section{Results}

Phellinus piptadeniae grows mostly on living legume species (Table 1). In the semideciduous forests of the Atlantic Forest domain in southeastern Brazil, P. piptadeniae was found exclusively growing on Piptadenia gonoacantha; whereas in the Caatinga dry woodlands, it was found recurrently on Piptadenia spp., but also on Mimosa and Senegalia. We also found the species on Libidibia glabrata (Kunth) Castellanos \& G.P.Lewis and Pithecellobium excelsum (Kunth) Mart. in seasonally dry forests of northwestern Peru. This greatly expands the geographic and host range of $P$. piptadeniae (Fig. 1).

The detailed analysis of type collection of $P$. piptadeniae as well as collections from Brazilian Caatinga and the newly collected specimens in southern Brazil and northwestern Peru revealed differences in the hyphal system and spore morphology when compared to the original species description. Hence, an updated detailed description is presented below.

\section{Discussion}

Morphology and taxonomic status

All the studied specimens presented a dimitic (generative and skeletal hyphae) hyphal system in the trama of tubes, but a monomitic context with generative hyphae only (Table 1; Fig. 3). This hyphal structure was not mentioned in the original description. Teixeira (1950) described two types of septate hyphae (branched and unbranched hyphae) in the basidiome structure. Skeletal hyphae restricted to the trama of the tubes were also not reported by Ryvarden (2004). We newly observed that the basidiospores are broadly ellipsoid to ellipsoid and present a xanthochroic reaction in $\mathrm{KOH}$ (Fig. 2). As such, Phellinus piptadeniae is recognized here in a wide sense, characterized by the combination of a perennial, triquetrous to ungulate basidiome, the upper surface of the pileus becoming rimose, with small scales, context layers between the tube strata, and a black line in the context (Fig. 2). Microscopically, it is characterized by a dimitic hyphal system in the trama of tubes, monomitic in the context, absence of setae, and ellipsoid to broadly ellipsoid, thick-walled, ventrally flattened, yellowish, and xanthochroic basidiospores. 


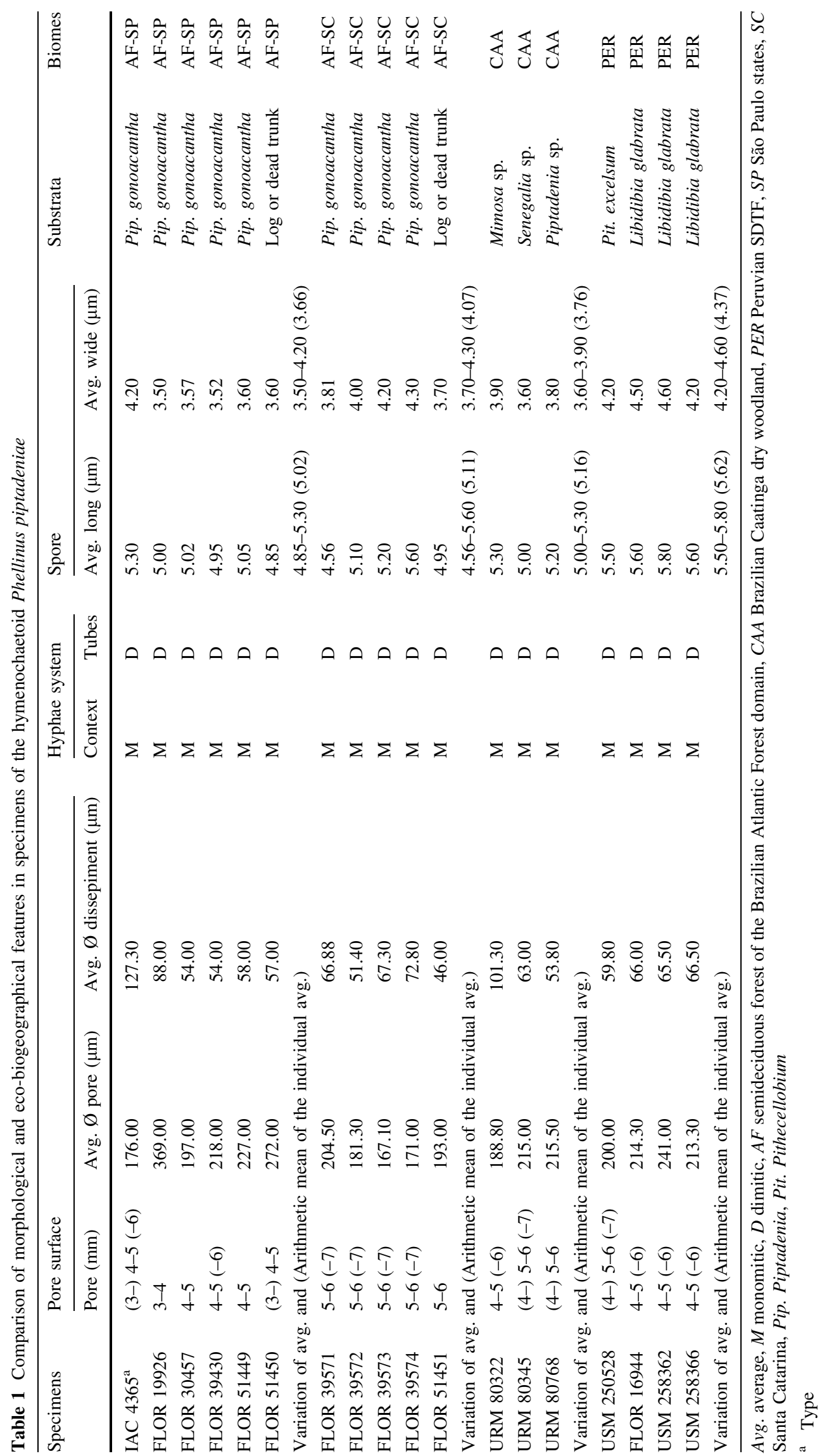


Fig. 1 Disjunct distribution of PheIllinus piptadeniae (red circles) in the South American Seasonally Dry Tropical Forest (SDTF) biome. The northernmost points in Brazil fall within the limits of the Caatinga dry woodlands, whereas southernmost points come from semideciduous or deciduous forests within the limits of the Brazilian Atlantic Forest domain. The records in Peru are from lowland seasonally dry forests. The distribution of the SDTFs follows Särkinen et al. (2011a), who modeled the biome using georeferenced herbarium plant specimen data of SDTF habitat specialist species

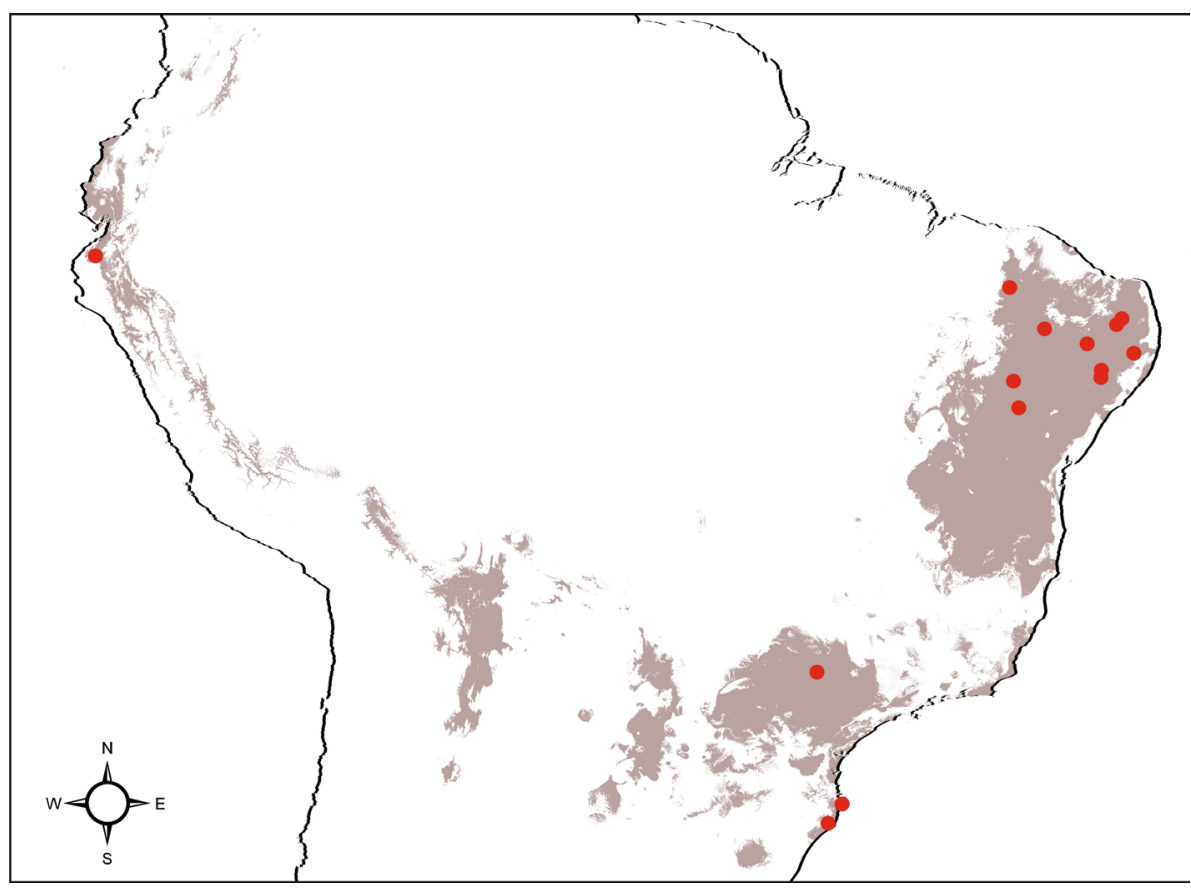

Although $P$. piptadeniae has been suggested to be conspecific with $P$. rimosus species complex (Ryvarden 2004), a recent study of morphology and ecology (Drechsler-Santos et al. 2010) revealed that these species are taxonomically distinct and have different ecological preferences, such as the host specialization on particular native plants. Phellinus piptadeniae frequently has a cracked pilear surface that is mostly glabrous and not deeply rimose when old (Fig. 2), in addition to the skeletal hyphae restricted to the tubes and a distinctive black line across the context (Fig. 2). These characters strongly support the identity of $P$. piptadeniae and clearly distinguish it from $P$. rimosus complex, which is widely recognized by the ungulate basidiome with a black and deeply rimose pilear surface, besides a dimitic hyphal system and rusty brown basidiospores (Kotlaba and Pouzar 1978).

Our concept of $P$. piptadeniae led us to include the 14 specimens newly collected during the polypore surveys in Peru and Brazil. Although the P. piptadeniae population from Peruvian lowland seasonally dry forests has strong morphological ties with the Brazilian Caatinga and Atlantic Forest populations, some differences between them are highlighted here (Table 1). For example, basidiospores of Brazilian specimens are slightly smaller $(5-5.5 \times$ $3.5-4 \mu \mathrm{m})$ than those of Peruvian specimens $(5.5-6 \times$ 4-4.5 $\mu \mathrm{m}$ ). In fact, the average size of the basidiospores, but in combination with geography and molecular data, has been taxonomically relevant to differentiate morphologically similar species, as outstandingly exemplified with the cryptic speciation of Fomitiporia Murrill in the Neotropics (Decock et al. 2007). Despite some morphological and ecological (e.g. distinct legume hosts) discontinuities among the allopatric populations of $P$. piptadeniae are clearly recognized, for the time being we maintain a wide taxonomic concept for the species, until further molecular studies are conducted.

The generic classification of $P$. piptadeniae in the new phylogenetic scenario of the Phellinus s.l. and Inonotus s.l. (Fiasson and Niemellä 1984; Wagner and Fischer 2002; Larsson et al. 2006) remains uncertain and should be further investigated. The combination of macro- and microcharacters of $P$. piptadeniae suggest that the species does not belong to Phellinus s.s., which is characterized by having dimitic hyphal system, hymenial setae, and hyaline to pale yellowish basidiospores (Wagner and Fischer 2002). The shared ellipsoid and colored basidiospores of $P$. piptadeniae, Fomitiporella Murrill, and Inocutis Fiasson \& Niemelä have long been used to indicate their close affinity (Teixeira 1992). When combining $P$. piptadeniae in Fomitiporella, Teixeira (1992) did not give any reason for the placement in this genus. He overlooked the black line in the context of $P$. piptadeniae as a taxonomically important character. Even in his later publication "Genera of Polyporaceae" (Teixeira 1994), the genus Fomitiporella, including $P$. piptadeniae, is described as having context without dark lines. We are convinced that $P$. piptadeniae does not belong to Fomitiporella because this genus traditionally comprises resupinate species, with strictly dimitic hyphal system and small basidiospores (Fiasson and Niemelä 1984; Wagner and Fischer 2002). Inocutis, on the other hand, has a monomitic hyphal system throughout the basidiome. Preliminary molecular phylogenetic 
evidence (Drechsler-Santos et al., unpublished data) show $P$. piptadeniae within a clade together with species of Fulvifomes, Fomitiporella, Inocutis, and Phylloporia Murrill, all of which characterized by lacking setae and having ellipsoid, flattened, thick-walled, and colored basidiospores (Fiasson 1982; Fiasson and Niemelä 1984; Wagner and Fischer 2002). That P. piptadeniae most likely will not be placed in Phellinus is becoming true. Notwithstanding, the phylogenetic relationship of $P$. piptadeniae in the context of the taxonomy of Phellinus s.l. and Inonotus s.l. is still far from being solved. Several changes are taking place in specific and generic classical concepts of the poroid Hymenochaetales, and many tropical species/lineages have not yet been included in molecular phylogenetic analyses (e.g., Wagner and Fischer 2002; Larson et al. 2006; Decock et al. 2007; Tian et al. 2013). Given that the phylogenetic analyses still poorly resolved lineages that could be equated to genera (Niemelä et al. 2001; Zhou and Qin 2013), we refrain to generate new combinations until robust molecular evidence is available. As such, we prefer to keep P. piptadeniae in its current generic classification to avoid proliferation of new scientific names (Murrill 1914; Fiasson 1982; Fiasson and Niemelä 1984).

Distribution, host range, and taxonomic implications

Phellinus piptadeniae was originally described from the Atlantic Forest of the Brazilian state of São Paulo (Teixeira 1950). After extensive field works in other neotropical seasonally dry forests, its geographic distribution is now considerably extended (Fig. 1). Although the Atlantic Forest is largely known to harbor wet forests, many enclaves of seasonally dry semideciduous or deciduous forests are scattered throughout. These enclaves of seasonally dry forests have floristic affinities with the SDTF biome (e.g. Amorim et al. 2005; Cardoso and Queiroz 2008; Oliveira-Filho et al. 2006, 2013). The modeled SDTF map of Särkinen et al. (2011a) gives a more realistic distribution of the biome in South America, clearly showing patches of seasonally dry forests within the limits of the Atlantic Forest domain. Therefore, $P$. piptadeniae might represent a new example of species with high ecological predilection for SDTF (Fig. 1).

Phellinus piptadeniae was supposed to grow exclusively on Piptadenia gonoacantha (Teixeira 1950), but here we have also expanded its host range (Table 1; DrechslerSantos et al. 2010). The emerging pattern is that $P$. piptadeniae is remarkably often associated with SDTF-inhabiting legume species. There exist many other potential angiosperm hosts in this biome (Drechsler-Santos et al. 2010) but why $P$. piptadeniae seems to prefer the legumes remains an open question. Leguminosae is the most species-rich plant family in the neotropical SDTFs (Lewis et al. 2006; Queiroz 2006; Linares-Palomino et al. 2011), where its diversification history date back from at least 20 Myr (Pennington et al. 2004, 2010; Lavin 2006; Queiroz and Lavin 2011; Särkinen et al. 2012). An interesting hypothesis to be addressed in the light of a molecular dating analysis of both hymenochaetoid and legume phylogenies is whether the legumes opened an ideal ecological niche for the establishment and evolution of $P$. piptadeniae geographically confined in the South American SDTFs.

The geographically isolated populations of $P$. piptadeniae in SDTFs matches with the general distribution pattern observed in bees (Zanella 2000), lizards (Werneck and Colli 2006), and myriad other species or clades of different plant families (e.g. Prado and Gibbs 1993; Prado 2000; Taylor and Zappi 2004; Lewis et al. 2006; Caetano et al. 2008; Pastore et al. 2010; Cardoso and Queiroz 2011; Carvalho-Sobrinho and Queiroz 2011; De-Nova et al. 2011; Govindarajulu et al. 2011; Oliveira et al. 2013; Cardoso et al. 2014). Prado and Gibbs (1993), Prado (2000) and Pennington et al. (2000) advocated that most plant speciation and geographical disjunction in the island-like distributed SDTFs were driven by the fragmentation of this once more widespread biome during wetter periods of the Pleistocene. However, new insights on the historical assembly of the SDTF have been revealed by timecalibrated phylogenies of geographically structured clades, which show the importance of phylogenetic niche conservatism, multiple dispersal events, and persistence of lineages for evolutionary periods that greatly transcend the Pleistocene (Pennington et al. 2004, 2009, 2010; Lavin 2006; De-Nova et al. 2011; Govindarajulu et al. 2011; Queiroz and Lavin 2011; Särkinen et al. 2012). Undoubtedly, a dated phylogeny of the hymenochaetoid clade of $P$. piptadeniae is required for reconstructing its historical biogeography in South American SDTFs and to evaluate the impact of Pleistocene fluctuations in its present-day distribution.

A densely sampled molecular phylogeny including multiple accessions certainly would also shed light whether the allopatric and morphologically relatively distinct populations of $P$. piptadeniae comprise three different species or just a widely distributed species with morphological variation in response to different hosts (Taylor et al. 2000). Studies in geographically disjunct SDTF plant clades have successfully identified cryptic species in the Brazilian Caatinga (Queiroz and Lavin 2011), Peruvian inter-Andean dry valleys (Pennington et al. 2011; Särkinen et al. 2011b), and Mesoamerican dry forests (Duno-deStefano et al. 2010; Govindarajulu et al. 2011). There is no study on speciation of fungi in SDTF, but the few examples from inter-continental disjunctions in closely related species have shown cryptic speciation followed by long- 

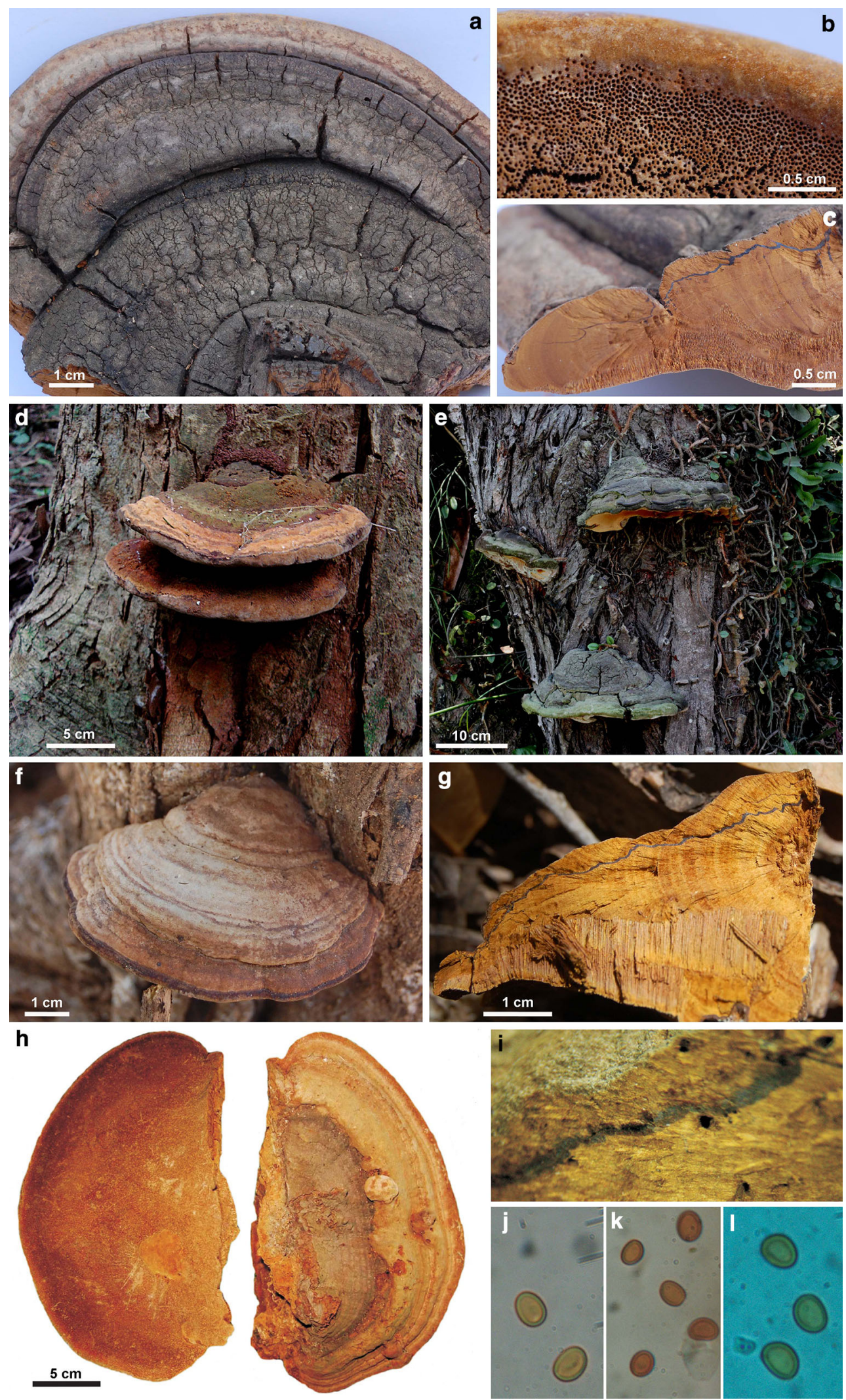
4Fig. 2 Macroscopical features of Phellinus piptadeniae. ac Paratype (IAC4365). a General view of the pilear surface. b Detail of the pore surface. c Basidiome in section showing context with a distinctive black line in the upper part and the tube layer.d, e Specimens from São Paulo (FLOR 30457) and Santa Catarina (FLOR 39574) states, respectively, both growing on Piptadenia gonoacantha. f, $\mathbf{g}$ Specimen from Caatinga dry woodlands of northeastern Brazil (Robledo 1981 CORD). f General view of the pilear surface. $\mathrm{g}$ Section thorough basidiome showing context with a black line in the upper part and the tube layer with thin contextual layers between tubes strata. h, i Specimen from Peru (USM 258362): $\mathbf{h}$ upper and pore surface, $\mathbf{i}$ close up of a section in the context showing the dark line. $\mathbf{j}-\mathbf{l}$ Basidiospores: $\mathbf{j}$ in lactophenol, $\mathbf{k}$ in $\mathrm{KOH} 3 \%$ (xanthochroic reaction), $\mathbf{l}$ in Cotton Blue

distance dispersal and geographical isolation (Halling et al. 2008; Moncalvo and Buchanan 2008; Liu et al. 2009). We expect that a revisit of $P$. piptadeniae based on phylogenetic analyses of DNA sequence variation will contribute to understand its biogeography and taxonomy and the diversification processes in the SDTF biome.

Taxonomic treatment

Phellinus piptadeniae Teixeira, Bragantia 10: 118. 1950. Figs. 1, 2, 3 .

$\equiv$ Fomitiporella piptadeniae (Teixeira) Teixeira, Revista Brasil Bot 15: 126. 1992.

Basidiome perennial, sessile, dimidiate, applanate, triquetrous to occasionally ungulate, solitary, up to $230 \mathrm{~mm}$ long, $190 \mathrm{~mm}$ wide and $83 \mathrm{~mm}$ thick, woody hard; pilear surface first pubescent and dark brown (HUE 7.5YR, 4/6), soon glabrous and dark grayish brown (HUE 2.5Y, 4/2) to olive gray (HUE 5Y, 4/2); concentrically wavy when young, latter turning sulcate with deep furrows delimiting wide lobes (mainly at the margin) and when well developed and mature present a regular, shallow, and radially concentric cracked (small scales like), occasionally some scrupose zones at the base are observed; margin entire, round to obtuse, pubescent and dark yellowish brown (HUE 10YR, 4/6) in the young or in active growth, when drying dark grayish brown (HUE $2.5 \mathrm{Y}, 4 / 2$ ); pore surface dark brown (HUE 7.5YR, 3/4); pores round, regular, (3-)4-6(-7) per mm, (170-)180-310(-340) $\mu \mathrm{m}$ diam., dissepiments entire, (30-)40-181(-200) $\mu \mathrm{m}$ thick; context up to $23 \mathrm{~mm}$ thick at the base in well-developed specimens, heterogeneous with a sinuous (following the relief of the pilear surface) black line that runs from the base to the margin, the basal layer dark yellowish brown (HUE 10YR, 4/6) and the upper one slightly darker; tubes indistinctly to distinctly stratified with a thin context layer, up to $15 \mathrm{~mm}$ long, dark brown (HUE 7.5YR, 3/4).

Hyphal system, monomitic in the context and dimitic in the trama of tubes; context dominated by generative a
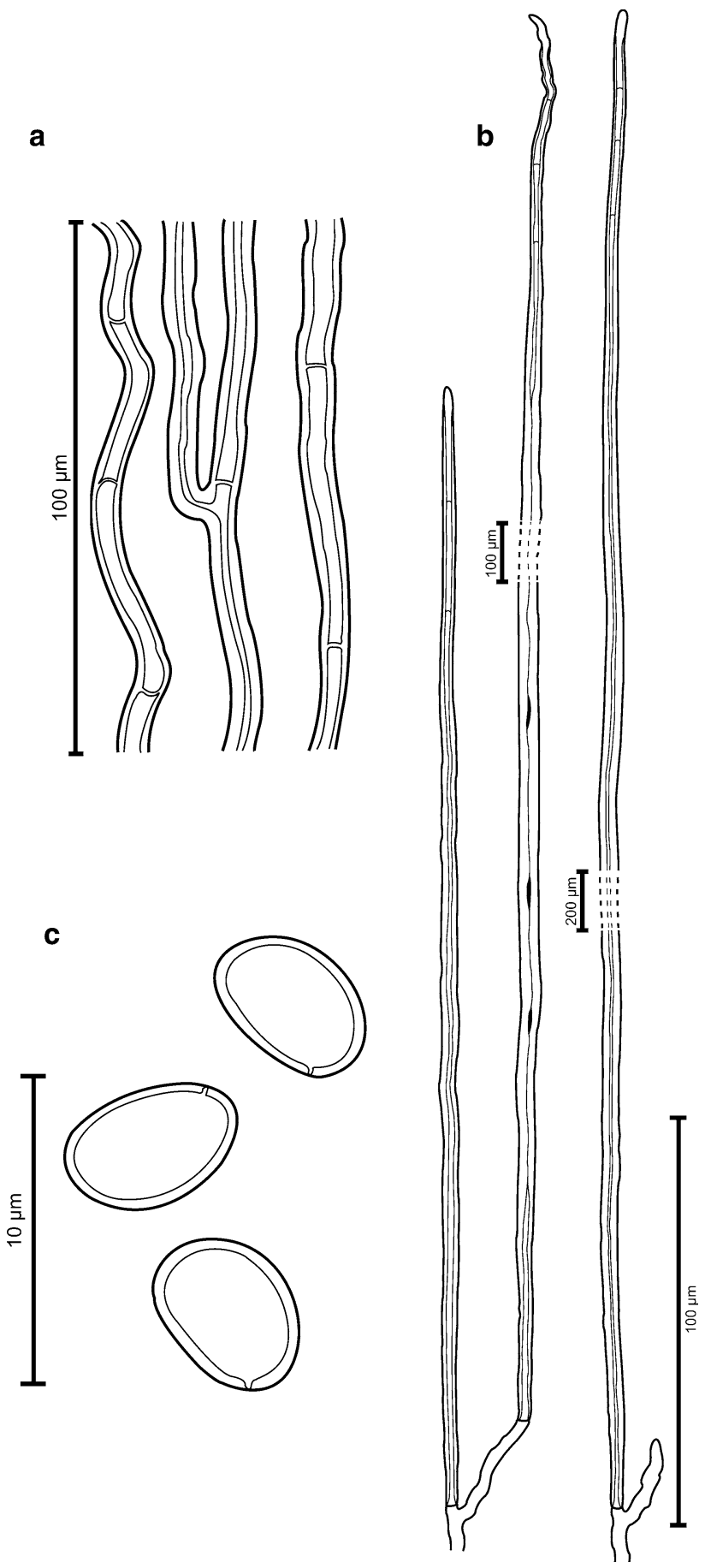

Fig. 3 Microscopical features of Phellinus piptadenniae: a Generative hyphae of the context with thick-walled; $\mathbf{b}$ skeletal hyphae of tubes, $\mathbf{c}$ basidiospores ellipsoid

hyphae, (2-)3-8(-10) $\mu \mathrm{m}$ diam, regularly septate, branched, thin-walled, gradually thick-walled, occasionally portions with few septa (skeletal-like hyphae) are observed; trama of tubes dimitic with thin- to slightly thickwalled generative hyphae, simple septate, branched, and unbranched skeletal hyphae, thick-walled with a visible 
lumen to almost solid, (230-)290-640(-750) $\mu \mathrm{m}$ long $\times(3-) 4-9(-10) \mu \mathrm{m}$ diam. $(\mathrm{L}$ avg. $=403 \mu \mathrm{m}, \mathrm{W}$ avg. $=5.1 \mu \mathrm{m})$, tapering to the apex where the wall is almost thin and three to four adventitious septa are present; setae absent; basidia not observed; basidiospores broadly ellipsoid to ellipsoid, with the ventral side flattened, (4-)4.5-6(-7) × (3-)3.5-4.5(-5) $\mathrm{mm}$ (L avg. = 5.3 $\mu \mathrm{m}, \mathrm{W}$ avg. $=4.1 \mu \mathrm{m}), \mathrm{Q}=1.1-1.5(\mathrm{Q}$ avg. = 1.3), thick-walled, smooth, pale yellow in lactophenol, showing a xantochroic reaction in $\mathrm{KOH}$ and basidiospores turning chestnut to ferruginous brown in $\mathrm{KOH}(\mathrm{KOH}+), \mathrm{CB}-$, IKI-.

Specimens examined-Brazil. São Paulo, Campinas, Município de Botucatu, trilha Ecológica Casa da Natureza, Fazenda Experimental do Lajeado, 30 Jan 2013, on live trunk of $P$. gonoacantha, M. Fernandes 7 (FLOR 19926), M. Fernandes 8 (FLOR 30457), 4 Jul 2013, on live trunk of $P$. gonoacantha, M. Fernandes 26 (FLOR 39430), M. Fernandes 27 (FLOR 51449), on log trunk of P. gonoacantha, M. Fernandes 29 (FLOR 51450); Santa Catarina, Florianópolis, Campus Universitário/UFSC, 25 Jan 2011, on live trunk of P. gonoacantha, M. A. BorbaSilva 106 (FLOR 39571), M. A. Borba-Silva 107 (FLOR 39572), 14 Apr 2011, on live trunk of $P$. gonoacantha, M. A. Borba-Silva 135 (FLOR 39573), M. A. Borba-Silva 136 (FLOR 39574), ibid. Tubarão, Fazenda Lunard, trilha do rio, 14 Nov 2012, on log trunk of P. gonoacantha, A. G. Silva-Filho 48 (FLOR 51451). Peru. Piura, Las Lomas, 7 Dec 2011, on live trunk of Pithecellobium excelsum, C. A. Salvador-Montoya 377 (FLOR 7554, USM 250528), 28 Aug 2012, on live trunk of Libidibia glabrata, C. A. Salvador-Montoya 454b (FLOR 16944), $C$. A. Salvador-Montoya 457b (FLOR 16945, USM 258362), C. A. Salvador-Montoya $461 b$ (FLOR 16946, USM 258366).

Additional specimens examined-Phellinus piptadeniae: Brazil. São Paulo, Campinas, Bosque dos Jequitibás, on Piptadenia communis, 12 Oct 1943, A. R. Teixeira \& P. R. Santos s.n. (IAC 4365, paratype); Pernambuco, Estação Experimental do IPA, Caruarú, 10 Dec 2008, on Mimosa sp., E. R. Drechsler-Santos 109PE (URM 80322), on Senegalia sp., E. R. Drechsler-Santos 110PE (URM 80345); ibid. Triunfo, 26 Nov 2009, on dead standing Piptadenia sp., Robledo 1981 (CORD); ibid. Serra Talhada, 5 Mar 2009, on Piptadenia sp., E. R. DrechslerSantos 139PE (URM 80768).

Acknowledgments The first author thanks José Cándido, Ana Vargas Celi, and Cindy F. Ruíz Febre for the important contribution during fieldwork. We thank the curators of USM and FLOR herbaria for providing access to collections; Tiina Särkinen for kindly making available the modeled map of the SDTF biome; to those responsible for the studied collecting areas; two anonymous reviewers for critically reading the manuscript; and Coordenação de Aperfeiçoamento Pessoal de Nível Superior (CAPES) for providing a master's scholarship to the first author (CAPES/PPGFAP/UFSC).

\section{References}

Amalfi M, Decock C (2013) Fomitiporia castilloi sp. nov. and evidence for multiples clades around $F$. apiahyna in Meso- and South America, representing potential species. Mycologia 105:873-887

Amorim AM, Jardim JG, Fiaschi P, Clifton BC, Carvalho AMV, Thomas WW (2005) The vascular plants of a forest fragment in Southern Bahia, Brazil. Sida 21:1727-1752

Caetano S, Prado D, Pennington RT, Beck S, Oliveira-Filho AT, Spichiger R, Naciri Y (2008) The history of seasonally dry tropical forests in eastern South America: inferences from the genetic structure of the tree Astronium urundeuva (Anacardiaceae). Molec Ecol 17:3147-3159

Cardoso DBOS, Queiroz LP (2008) Floristic composition of seasonally dry tropical forest fragments in Central Bahia, Northeastern Brazil. J Bot Res Inst Texas 2:551-573

Cardoso DBOS, Queiroz LP (2011) Caatinga no contexto de uma metacomunidade: evidências da biogeografia, padrões filogenéticos e abundância de espécies em Leguminosas. In: De Carvalho CJB, Almeida EAB (eds) Biogeografia da América do Sul: Padrões e processos. Roca, São Paulo, pp 241-260

Cardoso DBOS, Queiroz LP, Lima HC (2014) A taxonomic revision of the South American papilionoid genus Luetzelburgia (Fabaceae). Bot J Linn Soc 175:328-375

Carvalho-Sobrinho JG, Queiroz LP (2011) Morphological cladistic analysis of Pseudobombax Dugand (Malvaceae, Bombacoideae) and allied genera. Revista Brasil Bot 34:197-209

Decock C, Herrera-Figueroa S, Robledo G, Castillo G (2007) Fomitiporia punctata (Basidiomycota, Hymenochaetales) and its presumed taxonomic synonyms in America: taxonomy and phylogeny of some species from tropical/subtropical areas. Mycologia 99:733-752

De-Nova JA, Medina R, Montero JC, Weeks A, Rosell JA, Olson ME, Eguiarte LE, Magallón S (2011) Insights into the historical construction of species-rich Mesoamerican seasonally dry tropical forests: the diversification of Bursera (Burseraceae, Sapindales). New Phytol 192:276-287

Drechsler-Santos ER, Santos PJP, Gibertoni TB, Cavalcanti MAQ (2010) Ecological aspects of Hymenochaetaceae in an area of Caatinga (semi-arid) in Northeast Brazil. Fung Diversity 42:71-78

Drechsler-Santos ER, Gibertoni TB, Cavalcanti MAQ, Ryvarden L, Góes-Neto A (2013) Basidiomycota: Polypores-Orelhas de pau. In: Neves MA, Baseia IG, Drechsler-Santos ER, Góes-Neto A (eds) Guide to the common fungi of the semiarid region of Brazil, 1st edn. TECC Editora, Florianópolis, pp 51-82

Duno-de-Stefano R, Fernández-Concha GC, Can-Itza LL, Lavin M (2010) The morphological and phylogenetic distinctions of Coursetia greenmanii (Leguminosae): taxonomic and ecological implications. Syst Bot 35:289-295

Fiasson J (1982) Distribution of styrylpyrones in the basidiocarp of various Hymenochaetaceae (Aphyllophorales, Fungi). Biochem Syst Ecol 10:289-296

Fiasson JL, Niemelä T (1984) The Hymenochaetales. A revision of the European poroid taxa. Karstenia 24:14-28

Floudas D, Binder M, Riley R, Barry K, Blanchette RA, Henrissat B, Martínez AT, Otillar R, Spatafora JW, Yadav JS, Aerts A, Benoit I, Boyd A, Carlson A, Copeland A, Coutinho PM, De Vries RP, Ferreira P, Findley K, Foster B, Gaskell J, Glotzer D, Górecki P, Heitman J, Hesse C, Hori C, Igarashi K, Jurgens JA, 
Kallen N, Kersten P, Kohler A, Kües U, Kumar TKA, Kuo A, LaButti K, Larrondo LF, Lindquist E, Ling A, Lombard V, Lucas S, Lundell T, Martin R, McLaughlin DJ, Morgenstern I, Morin E, Murat C, Nolan M, Ohm RA, Patyshakuliyeva A, Rokas A, Ruiz-Dueñas FJ, Sabat G, Salamov A, Samejima M, Schmutz J, Slot JC, St John F, Stenlid J, Sun H, Sun S, Syed K, Tsang A, Wiebenga A, Young D, Pisabarro A, Eastwood DC, Martin F, Cullen D, Grigoriev IV, Hibbett DS (2012) The Paleozoic origin of enzymatic lignin decomposition reconstructed from 31 fungal genomes. Science 336:1715-1719

Govindarajulu R, Hughes CE, Bailey CD (2011) Phylogenetic and population genetic analyses of diploid Leucaena (LeguminosaeMimosoideae) reveal cryptic species diversity and patterns of allopatric divergent speciation. Amer J Bot 98:2049-2063

Halling RE, Osmundson TW, Neves MA (2008) Pacific boletes: implications for biogeographic relationships. Mycol Res 112:437-447

He SH, Dai YC (2012) Taxonomy and phylogeny of Hymenochaete and allied genera of Hymenochaetaceae (Basidiomycota) in China. Fung Diversity 56:77-93

Kotlaba F, Pouzar Z (1978) Notes on Phellinus rimosus complex (Hymenochaetaceae). Acta Bot Croat 37:171-182

Larsson KH, Parmasto E, Fischer M, Langer E, Nakasone KK, Redhead SA (2006) Hymenochaetales: a molecular phylogeny for the hymenochaetoid clade. Mycologia 98:926-936

Lavin M (2006) Floristic and geographical stability of discontinuous seasonally dry tropical forests explains patterns of plant phylogeny and endemism. In: Pennington RT, Lewis GP, Ratter JA (eds) Neotropical savannas and seasonally dry forests: plant diversity, biogeography and conservation. CRC Press, Boca Raton, pp 433-447

Lewis GP, Klitgaard BB, Schrire BD (2006) Seasonally dry forests of southern Ecuador in a continental context: insights from legumes. In: Pennington RT, Lewis GP, Ratter JA (eds) Neotropical savannas and seasonally dry forests: plant diversity, biogeography and conservation. CRC Press, Boca Raton, pp 281-314

Linares-Palomino R, Oliveira-Filho AT, Pennington RT (2011) Neotropical seasonally dry forests: diversity, endemism, and biogeography of woody plants. In: Dirzo R, Young HS, Mooney HA, Ceballos G (eds) Seasonally dry tropical forests: ecology and conservation. Island Press, Washington, pp 3-21

Liu M, Milgroom MG, Chavarri P, Hodge KT (2009) Speciation of a tropical fungal species pair following transoceanic dispersal. Molec Phylogenet Evol 51:413-426

Moncalvo JM, Buchanan PK (2008) Molecular evidence for long distance dispersal across the Southern Hemisphere in the Ganoderma applanatum-australe species complex (Basidiomycota). Mycol Res 112:425-436

Morim MP (2013) Piptadenia, in: Lista de Espécies da Flora do Brasil. Jardim Botânico do Rio de Janeiro. In: http://reflora.jbrj. gov.br/jabot/floradobrasil/FB31387

Munsell Color Company (1975) Munsell soil color charts, 1975th edn. Munsell Color Co., Baltimore

Murrill WA (1914) Northen polypores. The New Era Printing Company, New York

Niemelä T, Kinnunen J, Lindgren M, Manninen $\mathrm{O}$, Miettinen $\mathrm{O}$, Penttilä E, Turunen O (2001) Novelties and records of poroid Basidiomycetes in Finland and adjacent Russia. Karstenia 41:1-21

Oliveira LSD, Moro MF, Lughadha EMN, Martins FR, Melo AL, Esser HJ, Sales MF (2013) Hidden in the dry woods: mapping the collection history and distribution of Gymnanthes boticario, a well-collected but very recently described species restricted to the dry vegetation of South America. Phytotaxa 97:1-16

Oliveira-Filho AT, Jarenkow JA, Rodal MJN (2006) Floristic relationships of seasonally dry forests of eastern South America based on tree species distribution patterns. In: Pennington RT, Lewis GP, Ratter JA (eds) Neotropical savannas and seasonally dry forests: plant diversity, biogeography and conservation. CRC Press, Boca Raton, pp 59-192

Oliveira-Filho AT, Cardoso D, Schrire BD, Lewis GP, Pennington RT, Brummer TJ, Rotella J, Lavin M (2013) Stability structures tropical woody plant diversity more than seasonality: insights into the ecology of high legume-succulent-plant biodiversity. S African J Bot 89:42-57

Pastore JFB, Cardoso DBOS, Aymard GA (2010) A synopsis, new combinations, and synonyms in Acanthocladus (Polygalaceae). Novon 20:317-332

Pennington RT, Prado DA, Pendry C (2000) Neotropical seasonally dry forests and Pleistocene vegetation changes. J Biogeogr 27:261-273

Pennington RT, Lavin M, Prado DE, Pendry CA, Pell SK, Butterworth CA (2004) Historical climate change and speciation: neotropical seasonally dry forest plants show patterns of both Tertiary and Quaternary diversification. Philos Trans Ser B 359:515-538

Pennington RT, Lavin M, Oliveira-Filho A (2009) Woody plant diversity, evolution and ecology in the tropics: perspectives from seasonally dry tropical forests. Annual Rev Ecol Evol Syst 40:437-457

Pennington RT, Lavin M, Särkinen T, Lewis GP, Klitgaard BB, Hughes CE (2010) Contrasting plant diversification histories within the Andean biodiversity hotspot. Proc Natl Acad Sci USA 107:13783-13787

Pennington RT, Daza A, Reynel C, Lavin M (2011) Poissonia eriantha (Leguminosae) from Cuzco, Peru: an overlooked species underscores a pattern of narrow endemism common to seasonally dry neotropical vegetation. Syst Bot 36:59-68

Prado DE (2000) Seasonally dry forests of tropical South America: from forgotten ecosystems to a new phytogeographic unit. Edinburgh J Bot 57:437-461

Prado DE, Gibbs PE (1993) Patterns of species distributions in the dry seasonal forests of South America. Ann Missouri Bot Gard 80:902-927

Queiroz LP (2006) The Brazilian Caatinga: phytogeographical patterns inferred from distribution data of the Leguminosae. In: Pennington RT, Lewis GP, Ratter JA (eds) Neotropical savannas and seasonally dry forests: plant diversity, biogeography and conservation. CRC Press, Boca Raton, pp 121-157

Queiroz LP, Lavin M (2011) Coursetia (Leguminosae) from Eastern Brazil: nuclear ribosomal and chloroplast DNA sequence analysis reveal the monophyly of three Caatinga-inhabiting species. Syst Bot 36:69-79

Ryvarden L (2004) Neotropical Polypores. Part. 1. Oslo, Fungiflora, Synopsis Fungorum 19, p 229

Särkinen T, Iganci JRV, Linares-Palomino R, Simon MF, Prado DE (2011a) Forgotten forests-issues and prospects in biome mapping using Seasonally Dry Tropical Forests as a case study. BMC Ecol 11:27

Särkinen TE, Marcelo-Peña JL, Daza-Yomona A, Simon MF, Pennington RT, Hughes CE (2011b) Underestimated endemic species diversity in the dry inter-Andean valley of the Río Marañón, northern Peru: an example from Mimosa (Leguminosae, Mimosoideae). Taxon 60:139-150

Särkinen T, Pennington RT, Lavin M, Simon MF, Hughes CE (2012) Evolutionary islands in the Andes: persistence and isolation explain high endemism in Andean dry tropical forests. J Biogeogr 39:884-900

Taylor NP, Zappi D (2004) Cacti of Eastern Brazil. Royal Botanic Gardens, Kew, p 499

Taylor JW, Jacobson DJ, Kroken S, Kasuga T, Geiser DM, Hibbett DS, Fisher MC (2000) Phylogenetic species recognition and species concepts in fungi. Fung Genet Biol 31:21-32 
Teixeira AR (1950) Himenomicetos brasileiros-V Polyporaceae 2. Bragantia 10:113-122

Teixeira AR (1992) New combinations and new names in the Polyporaceae. Revista Brasil Bot 15:125-127

Teixeira AR (1994) Genera of Polyporaceae: an objective approach. Boletim da Chácara Botânica de ITU, no. 1, São Paulo, Brasil, p 91

Thiers B (2014) Index herbariorum: A global directory of public herbaria and associated staff. New York Botanical Garden's Virtual Herbarium. Website http://sweetgum.nybg.org/ih/

Tian XM, Yu HY, Zhou LW, Decock C, Vlasák J, Dai YC (2013) Phylogeny and taxonomy of the Inonotus linteus complex. Fung Diversity 58:159-169

Wagner R, Fischer M (2002) Proceedings towards a natural classification of the worldwide taxa Phellinus s.l. and Inonotus s.l., and phylogenetic relationships of allied genera. Mycologia 94:998-1016
Werneck FP, Colli GR (2006) The lizard assemblage from seasonally dry tropical forest enclaves in the Cerrado biome, Brazil, and its association with the Pleistocenic arc. J Biogeogr 33:1983-1992

Zanella FCV (2000) The bees of the Caatinga (Hymenoptera, Apoidea, Apiformes): a species list and comparative notes regarding their distribution. Apidologie 31:579-592

Zhou LW (2014) Fulvifomes hainanensis sp. nov. and F. indicus comb. nov. (Hymenochaetales, Basidiomycota) evidenced by a combination of morphology and phylogeny. Mycoscience 55:70-77

Zhou LW, Dai YC (2011) Phylogeny and taxonomy of Phylloporia (Hymenochaetales): new species and a worldwide key to the genus. Mycologia 104:211-222

Zhou LW, Qin WM (2013) Phylogeny and taxonomy of the recently proposed genus Phellinopsis (Hymenochaetales, Basidiomycota). Mycologia 105:689-696 